\title{
Red-Flagging Who? Combative Agendas Concerning Infants in New Zealand ECE
}

New Zealand Journal of Teachers' Work, Volume 11, Issue 2, 159-165, 2014

\author{
E.JAYNE WHITE \\ University of Waikato
}

The recent New Zealand Herald article (24.4.15)_-Early childcare services red-flagged"-is right to draw public attention to the present situation for infants in New Zealand early childhood education (ECE) settings. The article represents a provocative and emotive plea to resist the impending 'disaster' of poor quality ECE for young children, especially infants. Perhaps even a rescue is needed in this regard! Combined with a selection of unscientific 'examples of poor quality' the article acts as leverage for such an agenda-invoking images of humiliation, exclusion, neglect and ignorance on the part of teachers who work in ECE services. Who would not be upset to learn of such offences to 'innocent young lives' at the hands of negligent adults! A profoundly sinister agenda is thus posed at this juncture based on the vulnerable infant and the evil adult-an agenda all too easily inscribed on New Zealand teachers in other domains of education (see, for example Jones, 2004).

Such an emotively packaged agenda is problematic on a number of counts. Firstly it places responsibility for undesirable practice solely in the hands of adults who work with under-three-year olds in ECE. For the most part, as Peter Hughes (in his response to the Herald) points out, these are qualified professionals who take their work seriously and engage in on-going professional development to maintain high standards of practice. They often do so with inadequate funding, inadequately educated staff, (only $50 \%$ of teachers with ECE qualifications) minimal structural support and minimal professional (and public) recognition for the complexity of their work. These issues arise because of a new right agenda that does little to encourage locally relevant research into under-three's whilst endorsing privatised child care that is more easily persuaded to conform to minimal standards in order to make a profit. This agenda commodifies the status of infants and toddlers, emphasising long term 'cost-benefit' outcomes over relationships in the here-and-now (in other words, a deficit model emphasising baseline societal 'needs', such as minimising the cost of welfare over individual and cultural human experiences that necessarily exceed minimum standards of well-being). This neoliberal agenda effectively passes accountability to teachers when the fullest responsibility lies far beyond their individual or collective control. Perhaps worse still, it shifts blame to parents for the choices they make.

Notwithstanding the tremendous significance of teachers, these are highly emotive factors that underpin the phenomenon of families placing infants with adults outside of the home. The vulnerability of infants who cannot necessarily speak for themselves (Johansson, 2011) combined with the persuasive neurological evidence suggesting that the first two years of life are 
crucial to life-long well-being (Shonkoff, 2010) create a strong imperative for families to make choices that are in the 'best interests' of their infant. In a neoliberal society this may seem a reasonable assertion, yet, the choices families are able to make on behalf of their infants are often severely constrained economically, socially and educationally (Smith, 1996). In the midst of economic pressures that require parents to work, this is perhaps the most insidious agenda of all. As research has highlighted, there are associated effects impacting on the ECE experience when considered against child rearing practices that take place in the home (see, for example, Sammons, et al., 2007). In a country that cannot adequately care for children and their families living in poverty (White \& Pramling-Samuelsson, 2014) it seems rather ironic, therefore, that the present situation for infants in New Zealand should be so singularly targeted to ECE services. ECE is not a magic bullet-despite what the rhetoric might say.

Research to date overwhelmingly points to the significance of positive relationships as central to the well-being of infants. The relevance of the associated 'process dimensions' of quality (barely featured in the Herald article) are important regardless of whether these relationships take place at home or in an ECE context. Relationships thus lie at the heart of ECE curriculum, however, they are often overlooked in discussions about what constitutes learning for infants and toddlers in ECE. I suspect this is partially due to the overwhelming lack of understanding about what constitutes curriculum for this age groupthis, in spite of NZ's rich curriculum legacy as a world leader in this domain. In my recent research with infants in a New Zealand ECE service that met all the 'quality' dimensions, I had the privilege of witnessing many positive and lively interactions between infants and their teachers, infants and their peers (White, Peter \& Redder, 2015; White \& Redder, 2015). My observations highlight the potential of everyday routines, such as nappy changing or feeding, to invite rich opportunities for pedagogical engagement when adults understand and enact a relationship-based curriculum of education and care. Yet in the follow-up Herald article, "Babies needs at odds with tots learning" of 27 April 2015, there seems to be a residual Cartesian emphasis on 'activities' as opposed to relationships, further fuelling an apparent lack of public awareness of what it means to 'educate' in ECE. This blind-sided approach to learning in its fullest sense is further reinforced in the even more recent Education Review Office report (2015), which, among other things, emphasises the initiation of 'activities' as indicative of 'highly responsive' practice. To their credit ERO highlight the importance of interactions although they do not offer any clues as to what these might 'look like' in dialogues with infants and toddlers. I wonder if they know themselves?

These interactions constitute what I have come to describe as the 'dialogic space'-that is, the larger social space comprised of people, places and things who, together, represent the ECE curriculum experience for infants (White, 2014). When enacted alongside positive relationships with families, there is every good reason to accept the assertion that ECE is 'good for infants' and, indeed, may enrich the lives of all parties. Yet these relationships are subtle and are not easily 'measured' or prescribed. Interactions in ECE represent a sophisticated-sometimes-silent-form of pedagogy (White, Redder \& Peter, 2015; White \& Redder, 2015). It does not exist in isolation of either process or structural domains. Rather, quality curriculum resides in 
relationships between the two-for example, it does not take a rocket scientist to work out that meaningful dialogue is fostered best when both parties have opportunities for unhurried communication in peaceful, familiar contexts. Yet this kind of pedagogy is not yet well understood in the wider ECE sector let alone in political domains. It represents a much more sophisticated notion of subjective and objective 'quality' than our friends at the Herald are espousing, and, in my view, requires our urgent attention.

Instead of 'red-flagging' ECE services and, in the process, implicating teachers and families through accountability and guilt tactics, it would seem more productive to urge government to pay heed to the overwhelming importance of relationship-based experiences at the heart of curriculum for very young children in ECE, as already strongly highlighted by both New Zealand research (Dalli, et al., 2011) and international research (e.g. Trevarthen, et al., 2003)-all of which the Ministry is fully aware. While these results are compelling there is also a need to pay attention to more recent research that signals more cross-disciplinary approaches that take into account the fluctuating needs of young children (Institute of Medicine and National Research Council, 2015). In New Zealand there is additional scope to commission (or at least support) new research that tells a truthful and culturally relevant tale of the experience of infants in New Zealand-in ECE and at home. This is not an 'either-or' agenda but a relationship between the two locales in a new reality that will ideally support all parties to thrive both now and into the future. As such, these issues should be contemplated in tandem with socially just economic policies (such as generous paid-parental leave similar to the one year leave provided by Nordic countries) that support all families to live free of poverty, and thus be in a position to make real choices. In the same vein they ought to enable teachers to do their relational work with the support of infrastructures that exceed current minimum standards and celebrate a new kind of pedagogy that has much to offer education at large. Here we may think of structural features that underpin the 'quality' agenda, such as group size, ratio and qualifications; and what Dalli et al. (2011) describe as a 'membrane' of support that exists in supportive management structures and networks. These structures implicate us all.

Finally, in contemplating the red-flag effects of the Herald article, I want to suggest that it is imperative that these matters are not taken lightly or left to the destructive hype of public orators who seek simplistic solutions through the demonising of practice. If there is any red-flagging to be done I assert that this combative gesture should be targeted to those who represent New Zealand's 'best interests' in policy. In this regard we are all implicated-as policy-makers, citizens, advocates, researchers and voters. Infants and toddlers cannot, by themselves, march on parliament to have their voices heard. Indeed, their voices are startlingly absent from the existing research agenda, which has the capacity to inform policy (although, as Dalli et al. (2011) experienced, even government-commissioned reports find their recommendations falling on deaf ears). If the Herald article achieves anything at all (beyond guilt and blame tactics), it is to galvanise the public to recognise that quality is ECE is a complex issue that draws in multiple agendas and is ideologically driven. It will not go away. It is my hope, therefore, that the public will also realise that it is a political issue that can only be improved through the serious intervention of a government that is able to suspend other agendas to contemplate the infant (and the multiple adults surrounding them) at the centre of policy and practice. 
Not knowing and not doing is one thing, but knowing and still not doing is nothing short of immoral. 


\section{REFERENCES}

Dalli, C., White, E.J., Rockel, J., Duhn, I., with Buchanan, E., Davidson, S., Ganly, S., Kus, L., \& Wang, B. (2011). Quality early childhood education for under-two-year-olds: What should it look like? A literature review. Report to the Ministry of Education. Retrieved from http://www.educationcounts.govt.nz/_data/assets/pdf_file/0009/89532/9 65_QualityECE_Web-22032011.pdf

Education Review Office. (2015, June). Infants and toddlers: competent and confident communicators and explorers. Retrieved from http://www.ero.govt.nz/National-Reports/Infants-and-toddlers-competentand-confident-communicators-and-explorers-June-2015

Institute of Medicine and National Research Council. (2015). Transforming the workforce for children birth through age 8: A unifying foundation. http://www.nap.edu/download.php?record_id=19401

Johansson, E. (2011). Introduction: Giving words to children's voices in research. In Johansson, E. \& White, E.J. (Eds.). (2011). Educational research with our youngest: Voices of infants and toddlers, Springer: Dordrecht, Netherlands 1-13.

Johnston, K. (2015). Early childcare services red-flagged, The New Zealand Herald, 24 April. http://www.nzherald.co.nz/nz/news/article.cfm?c id=1\&objectid=1143523 5\&ref=NZH_FBpage

Jones, A. (2004). Safe practice casts teachers as abusers, New Zealand Herald, 7

December. http://www.nzherald.co.nz/opinion/news/article.cfm?c id=466\&objectid=9 001974

Sammons, P., Sylva, K., Melhuish, E., Siraj-Blatchford, I., Taggart, B., Barreau (2007). Influences on children's development and progress in key stage 2: Social/behavioural outcomes in year 5. (Research brief no. DCSF RB007).

Shonkoff, J. P. (2010). Building a new biodevelopmental framework to guide the future of early childhood policy. Child Development, 81(1), 357-367.

Smith, A.B. (1996). Is quality a subjective or objective matter. Paper presented at the National Seminar, "Assessing and Improving Quality in early Childhood Centres", Wellington, New Zealand. http://files.eric.ed.gov/fulltext/ED399015.pdf

Trevarthen, C., Barr, I., Dunlop, A.W., Gjersoe, N., Marwick, H., Stephen, C. (2003). Supporting a young child's needs for care and affection, shared meaning and a social place. Review of childcare and the development of children aged 0-3: Research evidence, and implications for out-of-home provision. Scottish Executive: United Kingdom. Retrieved from http://www.scotland.gov.uk/Resource/Doc/933/0007610.pdf 
White, E.J. \& Pramling-Samuelsson, I. (2014). Global crisis: Local reality - An international analysis of 'crisis' in the early years. Educational Philosophy and Theory, 46(9), 1036-1051. Doi: 10.1080/00131857.2014.931007

White, E.J., Redder, B. \& Peter, M. (2015). The Work of the Eye in Infant Pedagogy: A Dialogic Encounter of 'Seeing' in an Education and Care Setting. International Journal of Early Childhood, 47(2), 283-299.

White, E.J., Peter, M. \& Redder, B. (2015). Infant and teacher dialogue in education and care: A pedagogical imperative. Early Childhood Quarterly, 30, 160-173. doi:10.1016/j.ecresq.2014.10.008

White, E.J. \& Redder, B. (2015, online). Proximity with under two-year-olds in early childhood education: A silent pedagogical encounter. Early Education and Care. doi: 10.1080/03004430.2015.1028386 


\section{ABOUT THE AUTHOR}

\section{E.JAYNE WHITE \\ University of Waikato}

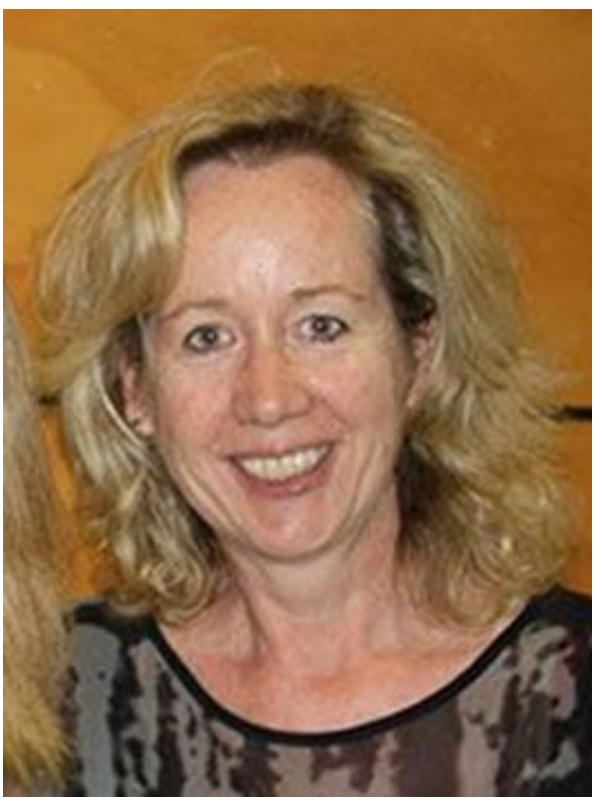

Jayne is an Associate Professor at University of Waikato where she teaches in undergraduate and postgraduate early years programmes. Jayne's primary domain of interest is dialogic pedagogies and related philosophies that have particular relevance to early childhood education today. She maintains a particular emphasis on the experience of infants and toddlers in this locale and was a member of the original Infant Advisory Group as well as co-author of the infant literature review commissioned by the Minister in 2011. Jayne's recent research focuses on the intersubjective and alteric dialogues that take place in early childhood education settings in an attempt to try to show what meaningful interactions 'look like' in this locale. She is co-editor of several journals and a new international Springer book series "Policy and Pedagogy for under-three-year olds" that seeks to bring these important issues to the fore in international scholarship.

\footnotetext{
The opinions expressed are those of the paper author(s) and not the New Zealand Journal of Teachers' Work. Copyright is held by individual authors but offprints in the published format only may be distributed freely by individuals provided that the source is fully acknowledged. [ISSN-1176-6662]
} 